\title{
Pragma-stylistic Analysis of Dramatic Texts: an overview
}

Ghada Elsayed M. Abdelrahman $^{(*)}$

\section{Abstract}

The main purpose of this research is to explore and analyze the language use in dramatic texts. The paper also aims to emphasize the connection between stylistics, literary criticism and critical theory. Stylistic methods have been used on a wide range of literary texts especially fiction and poetry; yet, stylistic analysis on dramatic texts has been challenging for several factors, which is the main reason it has been chosen in this study. Moreover, related previously published works and researches have helped pave the way for the application of such stylistic means.

\section{Defining Stylistics}

Stylistics is an inter-disciplinary field of study as it deals with literary texts from a linguistic point of view. Stylistics began to attract attention in the 1960s and became a significant research field by both linguists and literary critics. Roughly speaking, there are mainly two types of stylistics mainly textual and contextual. Formalist or textual stylistics regards literary works as an empirical autonomous unit of patterns and

(*) Demonstrator of English Literature, English Department, Faculty of Arts, Sohag University

This paper is part of an M.A. thesis entitled "A Pragma-stylistic Analysis of Three Plays by Donald Margulies", Supervised by Prof. Bahaa-eddin M. Mazid, Dean of the Faculty of Alsun, Sohag University \& Dr. Dr Thanaa Abdelraheem Al Qady, Lecturer of English Poetry at Faculty of Arts, Sohag University. 
structures and pays no attention to external factors that might have influenced the text while contextual stylistics obviously takes context into account (including social and ideological contexts) and uses a looser more comprehensive methods of analysis. As Richard Bradford indicates in his book Stylistics:

Contextualist stylistics is a broad church, and its various factions are united in their emphasis on the ways in which literary style is formed and influenced by its contexts. These involve (1) the competence and disposition of the reader; (2) the prevailing sociocultural forces that dominate all linguistic discourses, including literature; and (3) the systems of signification through which we process and interpret all phenomena, linguistic and non-linguistic, literary and nonliterary. (1997, p. 72)

Furthermore, Beatrix Busse points out: "Stylistics can trace its roots to the formalist tradition that developed in Russian literary criticism at the turn of the twentieth-century" (2010, p. 9). It is important to note as well the interdisciplinary nature it has: "From its emergence as an interdisciplinary blend of literary criticism, linguistics, psychology, cognitive science, social studies and philosophy, stylistics is now a mature and vibrant single discipline." (Stockwell et al., 2010, p. 1). It is an excellent example of a scientific branch that outgrows itself; it has gathered analytical tools in "pragmatics, text linguistics, discourse analysis, sociolinguistics, computational corpus linguistics and cognitive linguistics". (Stockwell et al., 2010, p. 2) Some of the established branches of stylistics are feminist stylistics, cognitive stylistics and corpus stylistics. 
Feminist stylistics concerns itself with how gender concerns are linguistically encoded in certain texts. As Sarah Mills observes: "analysis of language can help the reader be aware of ideologies of gender difference which are oppressive." (1995, p. 1) Feminist stylistcians use different sorts of discourse analysis to draw on social and ideological prejudices by showing the different perceived roles, behavior and characteristics of the two genders. Modern feminist stylistics disregards the notion that men and women write differently. A living proof to that claim is the contemporary Algerian writer Ahlam Mosteghanemi whose first person narrators are mostly males and she explores the male consciousness quite brilliantly. Therefore, it is concluded that the perceived difference of male and female styles has more to do with the mental expectations of the reader as dictated by social ideologies than with any genuine intrinsic difference.

Cognitive stylistics (also known as cognitive poetics) has its roots in psychology with I. A. Richards (one of the most influential figures in literary criticism) laying its foundation focusing on the relationship between speech, thought and intention. It draws on the fact that readers play an active role and studies reception and perception. As McIntyre et al claim: "cognitive stylistics focuses primarily on hypothesizing about what happens during the reading process and how this influences the interpretations that readers generate about the texts they are reading." (2010, p. 126) In other words, different readers may perceive different meanings as meaning is not located solely in the formal structures of the text but is 
negotiated as a result of readers utilizing aspects pf their preexisting background knowledge of the real world as they read." (McIntyre et al., 2010, p. 127)

On the other hand, corpus stylistics, which is a relatively recent field, combines corpus linguistics and literary theory. It relies heavily on the application of quantative methods to literary texts. The aim is to conduct a systematic analysis that is free of subjectivity by relying on computing methods. As Mahlberg points out: "Corpus stylistics is part of the much wider field of digital humanities that covers a range of methods and approaches of humanities computing to preserve, manipulate, process and make accessible not only texts but also other media and artefacts." (2012, p.5)

\section{Stylistics: Relation to literary theory}

Given its interdisciplinary nature, stylistic analysis is evidently a multi-level procedure. It is undoubted that literary theory and stylistics have a complementary relationship. One of the main aims of this study is to investigate the nature of such relationship drawing on the linguistic usage and artistic function.

Literary criticism works in two reverse ways; inside out, as it examines the poetics and aesthetics of the literary texts, yet it still involves outer factors including political, historical and social issues in which a certain text is produced and received. Stylistic analysis is another method applied to appreciate language and its use. Therefore, stylistics expands 
on theories in both literary and practical criticism in terms of the functionality and hermeneutics of language.

As Simpson puts it: "to do stylistics is to explore language, more specifically to explore creativity in language use." (2004, p. 3) Fowler also tends to believe that "linguistics can very appropriately and relatively be applied to literature [The best manner would be] to simply theorize literature as language, and to do this using the richest and most suitable linguistic models. (1988, p. 84) The marriage of linguistics with its scientific analysis on the discourse level and literary criticism and theory with its occupation with aesthetics can be very rewarding. As Burke observes "stylistics encourages literary criticism to be more than just opinions ... it is a kind of linguistic forensic literary discourse criticism" (2014, p. 3). It is evident that Stylistics "draws freely, and eclectically, on methods from both linguistics and literary study." (Cited in Missikova, 2003, p. 24) Therefore, a stylistician should be cognizant of the developments in linguistics, literary theory and discourse analysis.

It is similar to Russian Formalism in that it excludes any other extra-literal factors. In other words, "Stylistics is a method of textual interpretation in which primacy of place is assigned to language." (Simpson, 2004, p. 2)

To sum up, as Leech puts it the aim of stylistics is to combine the critic's concern with aesthetic appreciation with the linguist concern with language description. Among the most popular authors who wrote on this subject is Geoffrey Thurley who listed some of the major critical schools in the twentieth 
century in his book Counter Modernism in Current Critical Theory (1983), he added stylistics to his list. Fowler, as well had written quite a number of articles on the solid relationship between linguistics and literary theory comparing them to a bride and a groom including his Essays on Style and Language and Linguistic Criticism. He states that: "critical linguistics simply means an enquiry into the relations between signs, meanings and the social and historical conditions which govern the semiotic structure of discourse, using a particular kind of linguistic analysis" (Fowler 1991, p. 5). However, researchers who attempt to employ such relation should consider the points where those two fields can be utilized to the fullest, therefore an eclectic approach must be taken. Similarly, the renowned critic Terry Eagleton makes it clear in his book Literary Theory (1983) that literary criticism is not an autonomous field and that it should include scrutiny of language device after all language is the medium for composing literary texts.

\section{Style in a literary work}

If words and sentences were the garments that make the outfit, style is the accessories. It seems to be an elusive concept but style is the devices that the author employs to give a sense of uniqueness to the literary work. These devices include imagery, tone, voice, sentence structure, symbolism and point of view.

Different prominent writers have different distinct style. For instance, George Orwell is famous for his witty sublime writing style, while Hemingway is known for his blunt 
straightforward style. On the other hand, Jane Austen is renowned for her classy and lengthy sentences. Some tend to suppose that applying critical theory or stylistics to literary works can help evaluate them and differentiate between a good writer and mediocre one. On the other hand, others believe that this is not the function of stylistics. Stylistics is used to decipher different meanings in literary texts. This might seem like a purely subjective process, but it is made justifiable by linguistic technical supportive analysis and evidence. Using stylistic methods, one can also appreciate literary works. "Consequently, stylistics aims to explain the link between linguistic form and literary effect, and to account for what it is that we are responding to when we praise the quality of a particular piece of writing." (McIntyre, 2012, p. 1)

Burke also observes that the way we appreciate literature relies on the style "[...] in which the text is written or otherwise communicated, and how the characters are presented linguistically to you as reader, hearer or audience member." (2014, p. 118) Using stylistic methods seems to be a very useful tool in analyzing the language of literature specifically since it "was intended to provide a less intuitive, less personalized method of analysis, and one which was deliberately based on the scientific discipline of linguistics." (McRae \& Clark, 2004, p.329) It also aims at relating style to content and text to context.

Carter \& McCarthy trace how modern stylistics has little to no connection to the more traditional critical theories: 
In this way stylistics has shifted away from the Saussurian structuralism with which it was once commonly associated, and which saw the text as predominantly monologic, stale and self-referential towards a more Bakhtinian notion of dialogism and the recognition that artistic form and meaning emerge from the exchange of ideas between people. (1994, p. 10)

\section{Pragmatic Stylistics}

Pragmatics can be roughly defined as the study of language in use. Its basic concern is how language is used as a means of communication and interaction and how it is interpreted in certain given social, cultural and cognitive contexts. In other words, it "is the theory of human action which deals with the theoretical reconstruction of linguistic rules at action level as well as at form and meaning levels." (Bulut, 1994, p. 43). Pragmatics certainly transcends the word or even sentence level and concerns itself with many external factors while still using systematic methods and devices to reveal textual facts and phenomena. Levinson attempted and analyzed a number of definition of pragmatics, most appropriate of which is the following: "A theory of language understanding that takes context into account, in order to complement the contribution that semantics makes to meaning." (1983, p. 32). As Missikova puts it: "Within the process of stylistics analysis we study also the meanings which arise from the very act of communication taking place in a 
concrete situation. (2007, p. 93) Pragmatics approaches texts using a variety of technical devices which could be very helpful in the multi-layered process of stylistic analysis of literary texts. The methods and devices include but are in no way exclusive to: deixis, implicature, presupposition, speech acts and. conversational structure

Deixis simply refers to words that have no particular meaning separated from a certain context that adds "information" to them. Examples of such words include "this, that, here, there, and it". Levinson makes a very valid point when he indicates that deixis "concerns the ways in which languages encode or grammaticalize features of the context of utterance or speech event and thus also concerns ways in which the interpretation of utterances depends on the analysis of that context of utterance." (1983, p.54)

\section{Stylistic Methods and Dramatic Texts}

It is remarkable how "The study of meter, narrative and dramatic dialogue is founded upon the fundamental units and principles of all linguistic usage: phonemes, rhythmic sequences, grammatical classes, forms of syntactic organization and so on." (Bradford, 1997, p. xii) Nevertheless, applying stylistic methods to dramatic composition is a fruitful yet challenging pursuit since the length of the plays might pose an obstacle. Dialogue is one of the most important elements that make up a drama. Authors contrive dialogues between the different characters of a play. It might seem like everyday conversations but it is significantly different when it comes to 
discourse analysis. As Herman indicates, "it is a truism to say that drama dialogue differs from everyday speech. Drama dialogue clearly is fabricated interaction between fictional characters, mediated and controlled by playwrights in the first instance [...]" (2012, p. 41)

It happens to be a highly complicated process on so many levels as Simpson points out: "Analyzing play dialogue in terms of discourse strategy often involves cross-reference between the character level and the higher-order interactive level of playwright and audience/ reader". (2004, p. 86)

\section{List of References}

- Bradford, R. (1997). Stylistics. New York: Routledge.

- Bulut, A. (1994). A Macro Pragmatic Stylistic Framework for Fictional and non - Fictional text - Type Identification, Doctoral Dissertation, Gazi University.

- Burke, M. (2014). The Routledge Handbook of Stylistics. New York: Routledge.

- Busse, B. \& McIntyre, D. (eds.) (2010). Language, Literature and Stylistics, in McIntyre, D. and Busse, B. (eds) Language and style, pp. (3-14). Basingstoke:

Palgrave.

- Carter, R. \& McCarthy, M,. (1994). Language as Discourse: Perspectives for Language Teaching. London: Longman.

- Eaglton, T. (1996). Literary Theory: An Introduction. 2nd ed. Minnesota: Minnesota University Press. 
- Fowler, R. (1996). Linguistic Criticism, 2nd edition. Oxford: Oxford University Press.

- Fowler, R. (1996). Studying Literature as Language', in Jean Jaques. Weber (ed.), The Stylistic Reader: from Roman Jacobson to the present. London and New York: Arnold.

- Herman, V. (2002). Exploring the language of drama: from text to context. Culpeper, J. \& Short, M. \&Verdonk, P. (Eds). Routledge.

- Mills, S. (1995). Feminist Stylistics. New York: Routledge

- Levinson, S. (1983). Pragmatics. Cambridge: Cambridge University Press.

- McIntyre, D. \& Jeffries, L. (2010). Stylistics. Cambridge: Cambridge University Press

- McIntyre, D. (2012). Linguistics and literature: Stylistics as a Tool for The Literary Critic. Huddersfield: University of Huddersfield.

- Mahlberg, M. (2012). Corpus Stylistics and Dickens's Fiction. New York: Routledge.

- McRae, J. and Clark,V., (2004) Stylistics. In A. Davies and C. Elder, eds. The Handbook of applied linguistics. Oxford. Blackwell

- Missikova, G. (2003). Linguistic stylistics. Nitre: Univerzita Konštantína Filozofa v Nitre.

- Simpson, P. (2004). Stylistics: A Resource book for Students. Psychology Press.

- Stockwell, P., Lambrou, M. (2010). Contemporary Stylistics. London: A \& C Black. 